\title{
Serum Prolactin and Respiratory Distress Syndrome in the Newborn
}

\author{
YOLANDE F. SMITH, DARLENE K. MULLON, MARGIT HAMOSH, JOHN W. SCANLON, AND \\ PAUL HAMOSH
}

Departments of Pediatrics and Physiology and Biophysics, Georgetown University Medical Center, Washington, D. C.

\section{Summary}

Prolactin levels were measured in cord blood by radioimmunoassay in 57 premature infants between 26 and 36 weeks of gestation. The level of prolactin was in the range of 20 to $600 \mathrm{ng} /$ $\mathrm{ml}$. Twenty-three of the infants subsequently developed respiratory distress syndrome (RDS). The mean cord prolactin in the infants with RDS was $140 \pm 30.7 \mathrm{ng} / \mathrm{ml}$, whereas in the healthy infants it was $276.4 \pm 26.4 \mathrm{ng} / \mathrm{ml}$. Cord prolactin levels less than $140 \mathrm{ng} / \mathrm{ml}$ were associated with a high incidence of RDS: of 25 infants with prolactin levels of less than $140 \mathrm{ng} / \mathrm{ml}, 19(76 \%)$ had RDS. Of the 34 healthy infants, $28(82 \%)$ had prolactin levels above $140 \mathrm{ng} / \mathrm{ml}$. The highest levels $(500 \mathrm{ng} / \mathrm{ml})$ of prolactin in the group of infants with RDS were in two infants of diabetic mothers. The data suggest that prolactin might have a role in lung maturation in the human fetus.

\section{Speculation}

Prolactin is the latest hormone to be added to the list of hormones affecting lung maturation. Three groups have now reported a significant correlation between low cord prolactin levels and respiratory distress syndrome. The relative importance and mode of action of prolactin is unclear at present. Prolactin is present in very high concentration in amniotic fluid, and prolactin receptors are present in lung preparations. Prolactin might act as a direct trigger of lecithin synthesis or in a "chain reaction" along the hypothalamic-pituitary-adrenal axis. It could also be only an indicator of the degree of lung maturation. However, it is rapidly becoming clear that prolactin has a major role not only in lactation but also in fat metabolism, ion transport, and probably lung maturation.

Survival of the newborn infant depends primarily on its ability to establish effective ventilation. This ventilation is directly related to the presence of pulmonary surfactant in sufficient quantity to ensure alveolar stability (2). The precise mechanism that regulates fetal lung maturation is not clear at present. Acceleration of surfactant synthesis by corticosteroids and thyroxine has been demonstrated both in experimental animals $(6,17)$ and human subjects $(5,13)$. However, studies by Mesher et al. (14) suggest that cortisol is not a natural trigger of surfactant synthesis.

We have shown that administration of prolactin to fetal rabbits in utero leads within two days to a $67 \%$ increase in lung lecithin content (11), and we have suggested, therefore, that prolactin may be a physiological trigger of surfactant synthesis and lung maturation. Ballard et al. (3) have been unable to repeat our findings in rabbit fetuses. However, first Hauth et al. (12) then we (15) and Gluckman et al. $(9,10)$ have confirmed independently an association between incidence of respiratory distress syndrome (RDS) and low cord prolactin levels in premature infants. In this paper, we present our observations and compare the results with the other reports.

\section{MATERIALS AND METHODS}

The subjects of this study were 57 premature infants admitted to the neonatal intensive care units of Georgetown Medical Center Affiliated Hospitals, Washington, D. C. Gestational ages were in the range of 26 to 36 weeks; $23(40 \%)$ of the infants developed RDS.

\section{ESTIMATION OF GESTATIONAL AGE}

The gestational age of each infant was assessed on the basis of at least two of the following criteria: 1) examination according to Dubowitz et al. (7) within the first $48 \mathrm{hr}$; 2) date of last menstrual period; 3) ultrasonography; and 4) uterine size. The diagnosis of RDS was based on at least three of the following criteria: 1) oxygen requirement in first $24 \mathrm{hr}$ of life and ventilatory support; 2) Diffuse reticulogranular pattern on chest $X$-ray; 3) $\mathrm{L} / \mathrm{S}$ ratio and/or shake test; 4) clinical evaluation; and 5) autopsy evidence of hyaline membrane disease.

\section{HORMONE ASSAYS IN CORD BLOOD}

Mixed umbilical arterial and venous blood was collected at delivery in plain uncoated glass tubes and centrifuged, and the serum stored at $-20^{\circ}$ until assay.

Prolactin levels were measured by quantitative radioimmunoassay using a double antibody precipitation method $\left({ }^{125} \mathrm{I}\right.$ human prolactin kit; Calbiochem, La Jolla, CA).

\section{RESULTS}

In the group of 57 infants, $23(40 \%)$ developed RDS. Of these, $19(83 \%)$ had serum prolactin levels under $140 \mathrm{ng} / \mathrm{ml}$ at birth. Four $(17 \%)$ of the infants with prolactin levels under $140 \mathrm{ng} / \mathrm{ml}$ had no evidence of lung immaturity. Among the 34 infants with no evidence of RDS, $28(82 \%)$ had serum prolactin levels above $140 \mathrm{ng} / \mathrm{ml}$, and $6(18 \%)$ had serum prolactin levels under $140 \mathrm{ng} /$ $\mathrm{ml}$.

The relationship between gestational age and serum prolactin levels is presented in Figure 1. The mean serum prolactin level in the 23 infants with RDS was $140.4 \pm 30.7 \mathrm{ng} / \mathrm{ml}$, whereas that in the 34 healthy infants was $276.4 \pm 26.4 \mathrm{ng} / \mathrm{ml}(P<0.01)$. The correlation coefficient $(r)$ between gestational age and serum prolactin level was $0.53(P<0.01)$.

Table 1 represents the subdivision of these 57 infants according to gestational age, prolactin levels, and the presence or absence of RDS. The presence of RDS in 10 of 12 infants delivered between the gestational ages of 26 and 29 weeks illustrates the widespread incidence of RDS at this age. There were only two infants with serum prolactin levels over $140 \mathrm{ng} / \mathrm{ml}$, and one of these developed RDS. In this age group, nine of 10 infants with serum prolactin levels under $140 \mathrm{ng} / \mathrm{ml}$ developed RDS. In the group of 19 infants born between 30 and 32 weeks of gestation, six of 11 with serum prolactin levels under $140 \mathrm{ng} / \mathrm{ml}$ developed RDS. All eight infants with serum prolactin levels over $140 \mathrm{ng} / \mathrm{ml}$ remained healthy. In 


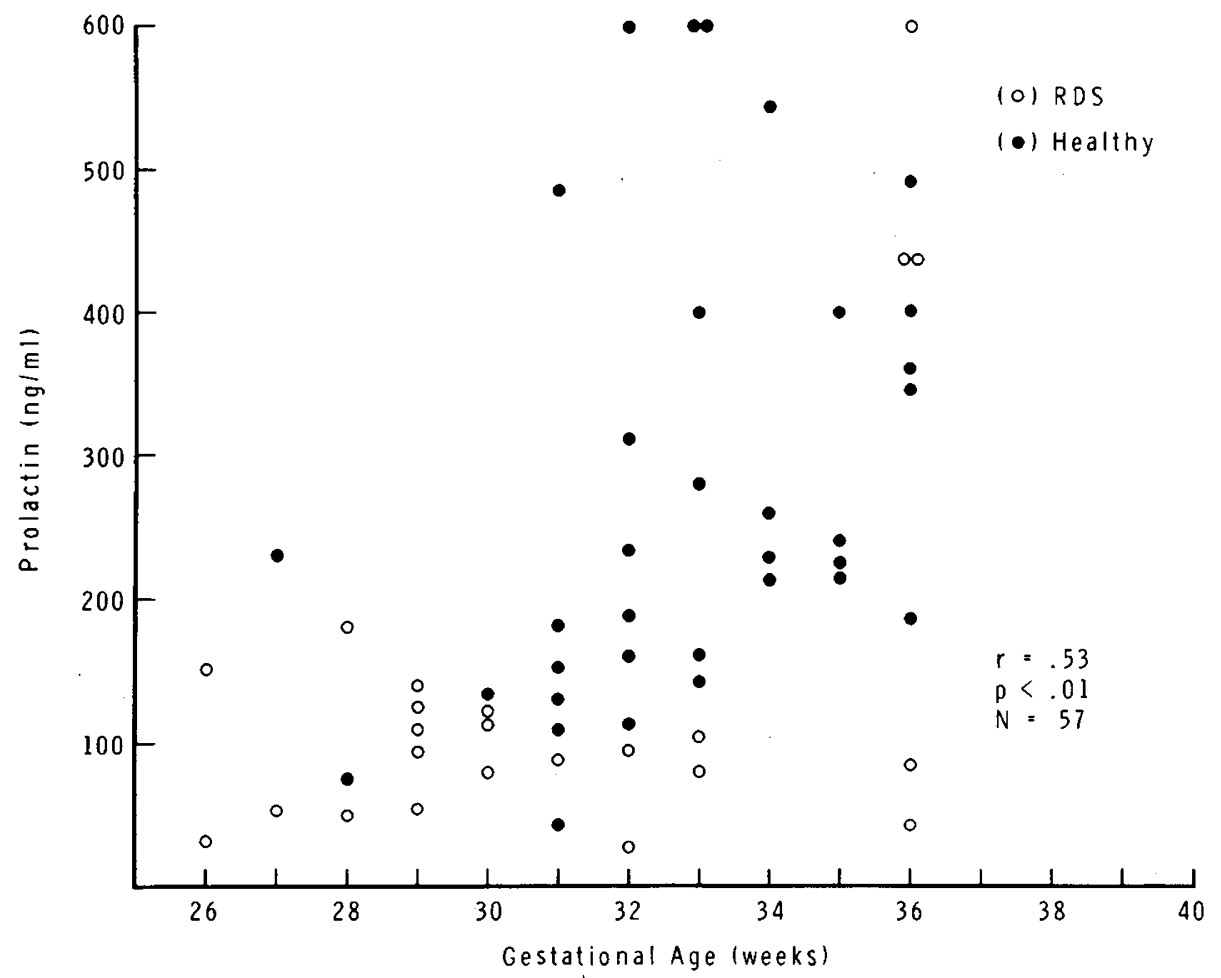

Fig. 1. Relationship between cord prolactin levels and gestational age in 57 premature infants. $\bigcirc$, infants who developed RDS; $\bullet$, healthy infants.

Table 1. Fetal prolactin and the incidence of RDS

\begin{tabular}{lcccccccc}
\hline & \multicolumn{8}{c}{ No. of newborn infants $^{1}$} \\
\cline { 2 - 9 } \multicolumn{1}{c}{ PROLACTIN LEVELS } & \multicolumn{9}{c}{ Healthy } & \multicolumn{3}{c}{ RDS } \\
\hline Gestational age (wk) & $26-29$ & $30-32$ & $33-36$ & $26-36$ & $26-29$ & $30-32$ & $33-36$ & $26-36$ \\
\hline hPRL $^{2}$ less than $140 \mathrm{ng} / \mathrm{ml}$ & 1 & 5 & 0 & 6 & 9 & 6 & 4 & 19 \\
hPRL more than $140 \mathrm{ng} / \mathrm{ml}$ & 1 & 8 & 19 & 28 & 1 & 0 & 3 \\
TOTAL & 2 & 13 & 19 & 34 & 10 & 6 & 7 & 23 \\
\hline
\end{tabular}

${ }^{1}$ There were 57 infants in the group.

${ }^{2}$ hPRL, human cord prolactin.

the group of 26 infants born after 33-36 weeks of gestation, only four had serum prolactin levels under $140 \mathrm{ng} / \mathrm{ml}$, and all four developed RDS. Of the three infants in this group who developed RDS in spite of serum prolactin levels in excess of $140 \mathrm{ng} / \mathrm{ml}$, two were born to diabetic mothers.

\section{DISCUSSION}

Liggins and Howie (13) have shown an acceleration of fetal lung maturation after administration of betamethasone. Although still controversial (16), the administration of betamethasone to expectant mothers likely to deliver prematurely is now an accepted therapeutic measure. Studies on the temporal relationship between the rise in plasma corticosteroid levels and the appearance of surfactant in the amniotic fluid have shown, however, that the rise in fetal lung surfactant precedes the rise in fetal serum cortisol levels (14). On the other hand, human fetal prolactin levels (1) rise prior to the increase in surfactant synthesis $(8)$. The possibility of a significant role for prolactin as a trigger of lung surfactant synthesis was suggested by the rapid increase in lung phospholipid levels in rabbit fetuses injected with prolactin (11). The failure of Ballard et al. (3) to repeat the results of this study are at present unclear. Cox and Torday (4) have recently reported increased dipalmitoyllecithin synthesis in cultured lung cells upon addition of prolactin.
The data presented above show a significant association between low fetal serum prolactin and the development of RDS in the newborn. Choosing the arbitrary cutoff value at $140 \mathrm{ng} / \mathrm{ml}$, the relationship between low prolactin level and RDS at gestational ages of 30 to 32 weeks is particularly striking. It is unclear at present whether low prolactin is only an indicator of lesser maturity or is causally related to surfactant maturation. On the other hand, the occasional cases of normal infants with relatively low levels of serum prolactin are a clear indication that prolactin is certainly not the only factor necessary for lung maturation. On the other hand, the occurence of RDS with a high serum prolactin in two infants born to diabetic mothers is a clear indication that high serum prolactin per se does not confer protection from RDS.

The findings in fetal rabbits (11) and cultured lung cells (4) and the independent observations of three groups of investigators (11, $12,15)$ in studies of human infants all suggest a role for prolactin in lung maturation.

\section{REFERENCES AND NOTES}

1. Aubert, M. L., Grumbach, M. M., and Kaplan, S. L.: The ontogenesis of human fetal hormones. III. Prolactin. J. Clin. Invest., 56: 155 (1975).

2. Avery, M., and Mead, J.: Surface properties in relation to atelectasis and hyaline membrane disease. Am. J. Dis. Child., 97: 517 (1959).

3. Ballard, P. L., Gluckman, P. K., Brehier, A., Kitterman, J. A., Kaplan, S. L., Rudolph, A. M., and Grumbach, M. M.: Failure to detect an effect of prolactin on pulmonary surfactant and adrenal steroids in fetal sheep and rabbits. $J$. 
Clin. Invest., 62: 879 (1978).

4. Cox, M. A., and Torday, J. S.: Relative increase in saturated lecithin in prolactintreated fetal lung cultures. Pediatr. Res., 12: 559 (1978)

5. Cuestas, R. A., Lindall, A., and Engel, R. R.: Low thyroid hormones and respiratory distress syndrome of the newborn. N. Engl. J. Med., 295: 297 (1976).

6. de Lemos, R. A., Shermeta, D. W., Knelson, J. H., Kotas, R., and Avery, M. E.: Acceleration of appearance of pulmonary surfactant in the fetal lamb by administration of corticosteroids. Am. Rev. Respir. Dis., 102: 459 (1970).

7. Dubowitz, L. M. S., Dubowitz, V., and Goldberg, C.: Clinical assessment of gestational age in the newborn infant. J. Pediatr., 77: 1 (1970).

8. Gluck, L, and Kulovich, M. V.: Lecithin/sphingomyelin ratios in amniotic fluid in normal and abnormal pregnancy. Am. J. Obstet. Gynecol., 115: 539 (1973).

9. Gluckman, P. D., Ballard, P. L., Kaplan, S. L., Liggins, G. C., and Grumbach, M. M.: Prolactin in umbilical cord blood and the respiratory distress syndrome. J. Pediat., 93: 1011 (1978).

10. Gluckman, P. D., Ballard, P. L., Kitterman, J. A., Kaplan, S. L., and Grumbach, M. M.: Fetal prolactin (PRL) and the respiratory distress syndrome (RDS). Pediatr. Res. (abstract), 12: 524 (1978).

11. Hamosh, M., and Hamosh, P.: The effect of prolactin on the lecithin content of

Copyright $(C) 1980$ International Pediatric Research Foundation, Inc. $0031-3998 / 80 / 1402-0093 \$ 02.00 / 0$ fetal rabbit lung. J. Clin. Invest., 59: 1002 (1977)

12. Hauth, J. C., Parker, C. R., Jr., MacDonald, P. C., Porter, J. C., and Johnston, J. M.: A role of fetal prolactin in lung maturation. Obstet. Gynecol., 51: 81 (1978).

13. Liggins, G. C., and Howie, R. N.: A controlled trial of antepartum glucocorticoid treatment for prevention of the respiratory distress syndrome in premature infants. Pediatrics, 50: 515 (1972).

14. Mescher, E. J., Platzker, A. C. G., Ballard, P. L., Kitterman, J.'A., Clements, J. A., and Tooley, W. H.: Ontogeny of tracheal fluid, pulmonary surfactant, and plasma corticoids in the fetal lamb. J. Appl. Physiol., 39: 1017 (1975).

15. Smith, Y. F., Mullon, D. K., Hamosh, M., Scanlon, J. W., and Hamosh, P.: Prolactin and human lung maturation. Pediatr. Res., 12: 569 (1978).

16. Taeusch, H. W.: Glucocorticoid prophylaxis for respiratory distress syndrome: A review of potential toxicity. J. Pediatr., 87: 617 (1975).

17. Wu, B., Kikkawa, Y., Orzalesi, M. M., Motoyama, E. K., Kaibera, M., Zigas, C. J., and Cook, C. D.: The effect of thyroxine on the maturation of fetal rabbit lungs. Biol. Neonate, 22: 161 (1973).

18. This research was supported by National Institutes of Health Grant HD 11353.

19. Received for publication December $19,1978$.

20. Accepted for publication March 14, 1979. 